\title{
CONSTITUENT GENETIC CHARACTERISTICS OF SCAD SPECIES (FAMILY CARANGIDAE) FROM BITUNG WATERS OF INDONESIA
}

\author{
Ondang Hetty M.P.*, Saranga Rudi, Tumanduk Nova Magdalena \\ Marine and Fisheries Polytechnic of Bitung, Indonesia \\ *E-mail: hettyondang@gmail.com
}

\begin{abstract}
The clusters of scad (Selar) which caught around Bitung waters so far has not been genetically confirmed, which has led to differences in the Bitung community's assumptions about the constituent species of Mackerel. The first assumption is that Scads in Bitung waters consist of 2 species only and the second assumption states that it consists of 3 species. To answer these problems, it is necessary to study validly the species based on genetic characteristics and nomenclature. There were 4 species of Scad caught in the waters around Bitung, covering Tude, Oci, Tude Batu and Ekor Kuning Napo according to the local names. This research aimed to obtain the genetic characteristics of Mackerel scad species and to obtain valid species according to the nomenclature. Data analysis was conducted using morphological and genetic approaches. The results showed the constituent genetic characteristics of the scad captured in the waters around Bitung. Based on DNA-COI analysis and nomenclature results, Tude and Oci species have 90\% similarity with each other and belong to the same species of Selar crumenophthalmus, Tude Batu is Selar boops with $90 \%$ similarity and Ekor Kuning Napo is Selaroides leptolepis with $98 \%$ similarity. From these results, it can be concluded that there are only 3 (three) species of scad seen from the nomenclature, namely Selar crumenophthalmus, Selar boops and Selaroides leptolepis.
\end{abstract}

\section{KEY WORDS}

Constituent species, genetic characteristics, Bitung waters, scad.

Indonesia is a country with the largest number of fish species in the world (Froese \& Pauly, 2011; Appeltans, 2012). Some researchers have noted that Indonesia has 8,500 fish species living in the waters, constituting $45 \%$ of the total global species in the world (Budiman et al., 2002), and has 2,500 species of marine fish (Sidarto, 1977 in Bailey et al.,1987). According to the Capture Fisheries Statistics of Indonesia issued by the Directorate General of Capture Fisheries (DJPT) of the Ministry of Maritime Affairs and Fisheries on the standard statistical classification of marine fish species, there are 91 names of fish clusters and 1 name for another fish species. Scad (Selar) is one of the many genera of Indonesian fishery catches, consisting of 2 clusters namely Selar and Bentong. The Selar cluster consists of Selaroides leptolepis species and the Bentong cluster consists of Selar crumenophthalmus and Selar boops species (DJPT, 2013). The naming system of Indonesian fish species is only based on the names of fish clusters and not based on fish species, causing a contradiction even errors in identification. This condition also informs that the naming system of fish species (fish names) in Indonesia has not been standardized and potentially leads to differences in assumptions and perceptions in fish species nomenclature.

A preliminary study with a morphological approach indicated 4 species of Selar fish caught around the Bitung waters, namely Tude, Oci, Tude Batu and, lastly Ekor Kuning Napo which is considered as a reef fish by the fishermen community. Some of the main characteristics of the Selar genus used for initial identification of its species are orbital diameter, black spots on the gill cover, scute, and yellow and orange stripes along the fish body. The differences in assumptions from the fishermen community and the common people in relation to the species of Selar caught in Bitung waters, which is interesting to study further to scientifically prove the two assumptions. The common people assume that the Selar genus in Bitung consists of three species, namely Tude, Oci, and Tude Batu while the fishermen community assumes that there are only two species of Selar, namely Tude or 
Oci and Tude Batu. It should be known that the fishermen community referred in this research were those carrying out fishing activities, collecting traders, retailers, and fish sellers while the common people referred in this research were those with a status of nonfisherman.

\section{METHODS OF RESEARCH}

This research was conducted from March to July 2018, where samples from each target fish species were separated using the main morphological features of each Selar species including scute shape, strip colour along the body, black spots on the gill cover, orbital diameter (eye size), head height, and jaw length. For the purpose of identifying characters morphometrically, the number of samples taken was 50 for each Selar species so that the total sample was 200 fishes, using 20 landmarks with 19 morphometric characters and 18 truss morphometrics.

Data of 19 truss morphometrics obtained from each species were arranged in the form of similarity and difference matrices using the Excel program. Then, it was analyzed using principal component analysis (PCA) to obtain a truss morphomatic grouping with the mechanism of plotting between PCA1 and PCA2 of one another species with SPSS 16.0 program. Cluster analysis was conducted to determine the level of species morphological kinship using hierarchical cluster analysis in a dendrogram.

The DNA analysis was carried out by taking the samples of fish back meat and then put it into a sample bottle (microtube) which was filled with $95 \%$ ethanol solution. There was only one part of a meat sample for each species to be analyzed so that the total sample for DNA analysis amounted to 4 samples. Before doing DNA isolation, the fish meat samples were temporarily stored in a freezer with a temperature of minus $40^{\circ} \mathrm{C}$.

Sequencing results were edited and analyzed using the BioEdit program (Hall, 1999). The sequences were done in two ways, namely forward $(\mathrm{F})$ and Reserve $(\mathrm{R})$, then aligned to obtain a consensus of nucleotide sequences. The alignment results were matched with the already available sequences in GenBank online (www.ncbi.nlm.nih.gov) through the Basic Local Alignment Search Tool (BLAST) (Altschul et al., 1997). Sequences of all species were analyzed using the Neighbour-Joining Tree method with the help of MEGA6 software (Tamura et al., 2013). The whole position of the sample was made in the default position with the number of bootstraps changed in the position of 1000 replications (Ikejima et al., 2004). Sequencing results from all individuals were compared with all the sequences of Selar crumenophthalmus, Selar boops, and Selaroides leptolepis originating from GenBank (https://www.ncbi.nlm.nih.gov). Phylogenetic reconstruction was carried out using the maximum-likelihood (Miligan, 2003) with the help of MEGA6 software.

\section{RESULTS AND DISCUSSION}

Based on morphological and morphometric approaches (Table 1) using the main characteristics of the Selar genus, this research obtained 3 (three) species of the Selar genus identified in Bitung waters, namely Selar crumenophthalmus (Bloch, 1973) for Oci species, Selar boops (Cuvier, 1833) for Tude Batu species, and Selaroides leptolepis (Cuvier, 1833) for Ekor Kuning Napo species. Specifically, the Tude species has not been able to be categorized in the three species mentioned above due to the different morphology, allegedly belonging to the sub-species of $S$. crumenophthalmus. Therefore, it was necessary to confirm it genetically to ensure the species was valid. Measurement of morphological characters can be used as special characteristics and relationship variations in the taxonomy of fish clusters (Misra \& Easton, 1999). The most important morphological characters in distinguishing the 4 (four) species of Selar fish caught in Bitung waters include scute, eye diameter, black spots on the gill cover, yellow and orange strips along the body, jaw length, and mouth shape. 
Table 1 - Morphometric Measurement (Average + Standard Deviation) of Selar clusters in Bitung Waters

\begin{tabular}{lcccc}
\hline \multicolumn{1}{c}{ Morphological Character } & Tude & Oci & Tude Batu & Ekor Kuning Napo \\
\hline Standard Length (SL) $(\mathrm{mm})$ & $149.65 \pm 9.44$ & $203.88 \pm 9.44$ & $186.96 \pm 16.19$ & $173.33 \pm 5.19$ \\
Comparison with SL: & & & & \\
Head Length & $0.26 \pm 0.33$ & $0.28 \pm 0.33$ & $0.30 \pm 0.01$ & $0.26 \pm 0.01$ \\
Pre Dorsal Length & $0.32 \pm 0.32$ & $0.31 \pm 0.40$ & $0.37 \pm 0.01$ & $0.35 \pm 0.01$ \\
Pre Ventral Length & $0.31 \pm 0.37$ & $0.33 \pm 0.37$ & $0.35 \pm 0.01$ & $0.31 \pm 0.01$ \\
Pre Pectoral Length & $0.27 \pm 0.34$ & $0.28 \pm 0.33$ & $0.29 \pm 0.01$ & $0.26 \pm 0.02$ \\
Second anal fin base length & $0.06 \pm 0.36$ & $0.29 \pm 0.34$ & $0.19 \pm 0.01$ & $0.36 \pm 0.01$ \\
Anal fin base total length & $0.32 \pm 0.44$ & $0.29 \pm 0.40$ & $0.39 \pm 0.02$ & $0.44 \pm 0.01$ \\
Second dorsal fin base length & $0.16 \pm 0.39$ & $0.33 \pm 0.38$ & $0.54 \pm 0.01$ & $0.40 \pm 0.02$ \\
Dorsal fin base total length & $0.37 \pm 0.58$ & $0.48 \pm 0.56$ & $0.54 \pm 0.02$ & $0.56 \pm 0.02$ \\
Dorsal Body Depth & $0.79 \pm 0.93$ & $0.75 \pm 0.92$ & $0.94 \pm 0.04$ & $0.25 \pm 0.01$ \\
Comparison with HL: & & & & \\
Snout length & $0.31+0.38$ & $0.32+0.38$ & $0.34+0.02$ & $0.36+0.01$ \\
Eye diameter & $0.26+0.32$ & $0.29+0.34$ & $0.31+0.03$ & $0.27+0.01$ \\
Post-orbital length & $0.34+0.44$ & $0.34+0.42$ & $0.37+0.03$ & $0.39+0.02$ \\
First anal fin base length & $0.07+0.23$ & $0.06+0.21$ & $0.19+0.04$ & $0.25+0.02$ \\
Pectoral fin length & $0.31+0.37$ & $0.33+0.37$ & $0.35+0.01$ & $0.29+0.01$ \\
Anal Height & $0.82+1.00$ & $0.76+0.96$ & $0.97+0.03$ & $0.27+0.02$ \\
First dorsal fin base length & $0.07+0.23$ & $0.32+0.21$ & $0.45+0.10$ & $0.58+0.03$ \\
Jaw length & $0.30+0.46$ & $0.40+0.48$ & $0.45+0.03$ & $0.41+0.02$ \\
Maximum scute width & $0.11+0.19$ & $0.10+0.13$ & $0.22+0.02$ & $0.08+0.01$ \\
\hline
\end{tabular}

Information obtained from Table 1 above suggests that several truss morphometric values resulted from this research are different from previous studies although the difference is not too significant. This is mainly because the studied fishes had different sizes and the fish sampling locations were also geographically different. The causal factors for variations in size on the measurement of fish parameters despite in the same species consist of sample fish sizes, genetic factors, water conditions, and growth. The other possible factors include differences in genetic structures, water environment conditions, ecological conditions, geographical isolation and environmental factors of physical waters where various species of fish inhabit (Tzeng et al., 2000; Naesjeetal, 2004; Poulet et al., 2004).

Table 2 - Comparison of $S$. crumenophthalmus truss morphometric values of previous studies with this research (Bitung)

\begin{tabular}{|c|c|c|c|}
\hline Morphometric truss values & Results of Previous Studies & Location & Results of this research (Bitung) \\
\hline $\begin{array}{l}\text { MSW: OD } \\
\text { (maximum scute width: orbital diameter) }\end{array}$ & $\begin{array}{c}2.1-2.9 \\
\text { (Carpenter \& Niem. 2001) }\end{array}$ & Pacific Ocean & 2.67 \\
\hline $\begin{array}{l}\text { OD: HL } \\
\text { (orbital diameter: head length) }\end{array}$ & $\begin{array}{c}0.39 \\
(\text { Allan. } 2001 \mathrm{a})\end{array}$ & Philippines & 0.37 \\
\hline $\begin{array}{l}\text { SNL: HL } \\
\text { (snout length: head length) }\end{array}$ & $\begin{array}{c}0.26 \\
\text { (Allan. 2001a) }\end{array}$ & Philippines & 0.35 \\
\hline $\begin{array}{l}\text { OD: HL } \\
\text { (orbital diameter: head length) }\end{array}$ & $\begin{array}{c}0.33 \\
\text { (Reyes. 1993a) }\end{array}$ & Philippines & 0.32 \\
\hline $\begin{array}{l}\text { SNL: HL } \\
\text { (snout length: head length) }\end{array}$ & $\begin{array}{c}0.25 \\
\text { (Reyes. 1993a) }\end{array}$ & Philippines & 0.35 \\
\hline
\end{tabular}

Table 3 - Comparison of $S$. boops truss morphometric values of previous studies with this research (Bitung)

\begin{tabular}{|c|c|c|c|}
\hline Morphometric Truss Values & Results of Previous Studies & Location & Results of this research (Bitung) \\
\hline $\begin{array}{l}\text { DBD: TL } \\
\text { (dorsal body depth: total length) }\end{array}$ & $\begin{array}{c}0.26 \\
\text { (Reves 1993b) }\end{array}$ & Philippines & 0.27 \\
\hline $\begin{array}{l}\mathrm{HL}: \mathrm{TL} \\
\text { (head length: total length) }\end{array}$ & $\begin{array}{c}0.23 \\
\text { (Reyes. 1993b) }\end{array}$ & Philippines & 0.28 \\
\hline $\begin{array}{l}\mathrm{PPL}-\mathrm{TL} \\
\text { (pre-pectoral length: total length) }\end{array}$ & $\begin{array}{c}0.23 \\
\text { (Reyes. 1993b) }\end{array}$ & Philippines & 0.32 \\
\hline $\begin{array}{l}\mathrm{OD}-\mathrm{HL} \\
\text { (orbital diameter: head length) }\end{array}$ & $\begin{array}{c}0.39 \\
\text { (Reyes. 1993b) }\end{array}$ & Philippines & 0.31 \\
\hline
\end{tabular}


Furthermore, the information presented in Table 2, 3, and 4 indicates that there is a slight difference in the truss morphometric values between previous findings taken from the site http://www.fishbase.org and the results of this research which was conducted in Bitung waters. In morphometric measurements on previous findings, there was only one fish taken as the measurement sample. Meanwhile, the number of sample fish used in this research was 50 for each Selar species, so the total sample amounted to 200 fishes. The measurement results of each species then used the average value of the 50 sample fish for each morphometric truss value. This is thought to be the cause of the differences in truss morphometric values obtained. Kharat et al. (2008) stated that the occurrence of differences in measurement results could be due to differences in the number and variation in the sampling size of fish used as the object of research.

Table 4 - Comparison of $S$. leptolepis morphometric truss values of previous studies with this research (Bitung)

\begin{tabular}{lccc}
\hline \multicolumn{1}{c}{ Morphometric Truss Values } & $\begin{array}{c}\text { Results of Previous } \\
\text { Studies }\end{array}$ & Location & $\begin{array}{c}\text { Results of this research } \\
\text { (Bitung) }\end{array}$ \\
\hline $\begin{array}{l}\text { SL - OD } \\
\text { (Scute length: orbital } \\
\text { diameter) }\end{array}$ & $\begin{array}{c}2.1-2.9 \\
\text { OD - HL } \\
\text { (Orbital diameter: head }\end{array}$ & $\begin{array}{c}\text { Pacific } \\
\text { Ocean }\end{array}$ & 2.67 \\
$\begin{array}{l}\text { length) } \\
\text { SL }- \text { HL } \\
\text { (Scute length: head length) }\end{array}$ & 0.26 (Allan. 2001b) & Philippines & 0.32 \\
$\begin{array}{l}\text { OD - HL } \\
\text { (Orbital diameter: head }\end{array}$ & 0.33 & Philippines \\
length) \\
$\begin{array}{l}\text { SL }- \text { HL } \\
\text { (Scute length: head Length) }\end{array}$ & 0.33 (Reyes. 1993c) & Philippines & 0.35 \\
\hline
\end{tabular}

The morphological and morphometric characters of the 4 (four) Selar species identified in Bitung waters had a different range of values. Thus, to cluster the morphometric truss values, PCA analysis was carried out. Cluster analysis using the main component (PCA1) and PCA2 obtained a morphological clustering distribution of each species based on the truss morphometric values (Figure 1). The analysis results showed that 4 clusters of truss morphometric distribution were formed based on the fish species. In other words, it can be informed that the 4 Selar species caught in Bitung waters had different morphological characters and could be assumed to be different species.

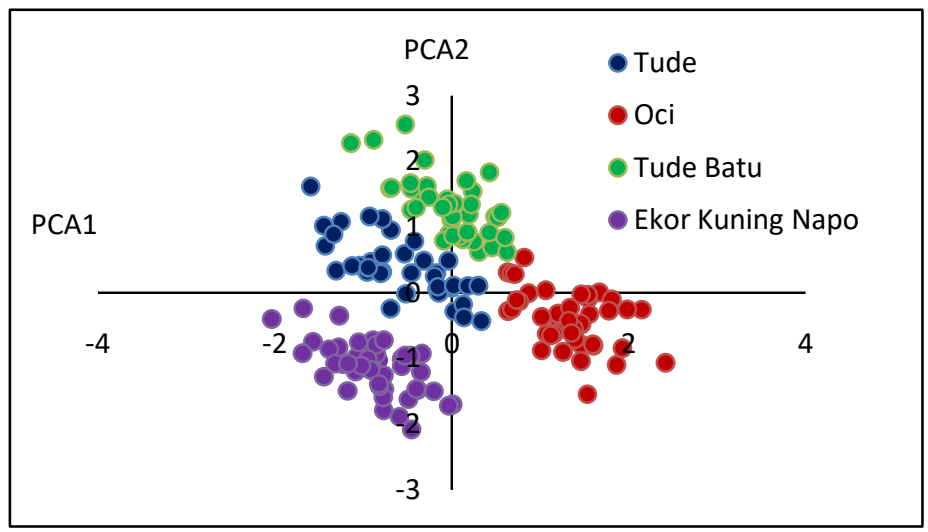

Figure 1 - PCA1 and PCA2 Plots of Truss Morphometric Values n

The grouping of Selar species based on truss morphometric values (Figure 1) resulted from the PCA analysis based on 20 morphological characters shows that the dot position for Ekor Kuning Napo species is in the left downward (purple dots), that for Oci species is in the right slightly downward (red dots), that for Tude species is in the center leaning upward (blue 
dots), and that for Tude Batu is in the center slightly upward (green dots). Morphological variations between species can be influenced by environmental ecological conditions and food availability (Muchlisin \& Fajri, 2015).

The results of the hierarchical cluster analysis in the form of a dendrogram (Figure 2) inform that based on the morphological characters of Selar caught in the waters of Bitung, there were 3 clusters found. Cluster I consisted of Tude and Tude Batu Selar species which had a fairly close linkage distance of 0.1. Furthermore, Cluster II consisted of Oci Selar species and the two Selar species of Cluster I (Tude and Tude Batu) with a linkage distance of 0.15 while Cluster III consisted of Ekor Kuning Napo Selar species which were separated from Cluster I and II with a linkage distance of 1.05 .

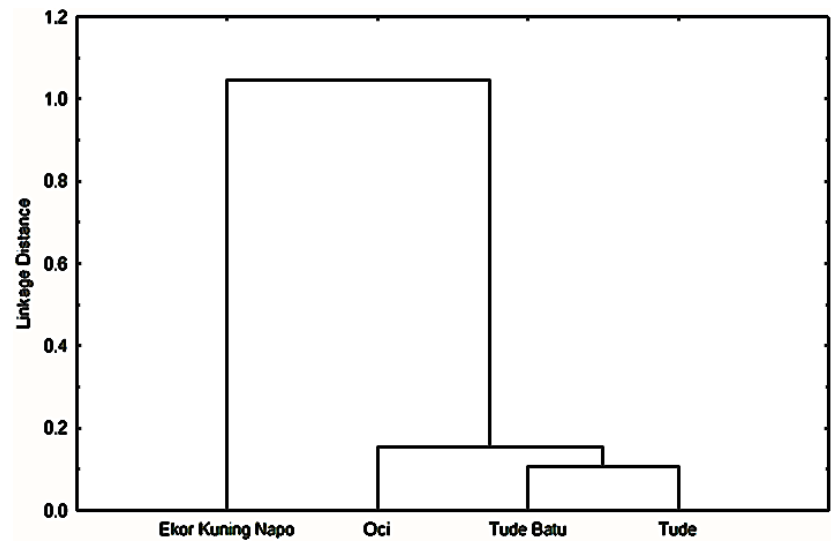

Figure 2 - Dendrogram of Hierarchical Cluster Analysis of 4 Species of Selar Fish Caught in the Waters around Bitung

The PCA analysis of morphological characters of Selar genus in the waters around Bitung suggests that there were 4 Selar clusters or species formed (Figure 11) while the hierarchical cluster analysis in the form of a dendrogram (Figure 2) indicates 3 Selar clusters or species, causing doubts in determining valid species. Each species has different morphological characters, so genetic clarification and confirmation need to be done through DNA-COI to ascertain and prove whether Selar fish caught in the waters around Bitung consists of 4 species or 3 species. With these results, it can be learned that it is very difficult to determine a fish species in the same genus only based on differences in morphological characters, so it needs to be integrated with genetic analysis to determine validly the species. Victor et al. (2009) stated that in many cases, it is very difficult to identify fish using only the morphological characteristics. Wiadnya et al. (2015) argued that morphological identification is not enough to ensure a species of fish despite having differences, so genetic confirmation is required.

From the phylogenetic reconstruction using the neighbour-joining method (Figure 3) and the maximum likelihood method (Figure 4), it can be obtained that Tude and Oci Selar species had a similarity value of $90 \%$, concluding that these two species are included in one species, namely Selar crumenophthalmus. The results of phylogenetic reconstruction using the BLAST method with sequences from the GenBank showed that Tude and Oci Selar species had a similarity value of $90 \%$ with a sequence of JF494491.1. These results prove to the people of Bitung that Tude and Oci Selar species which have been assumed to be different species turned out to be similar based on their morphological and morphometric characteristics. Meanwhile, Tude Batu Selar species had a similarity value of $90 \%$ with a sequence of JX261008.1, concluding that Tude Batu Selar species is Selar boops species. Lastly, Ekor Kuning Napo Selar species showed a similarity value of $98 \%$ with a sequence of JX261390.1 so that it can be concluded that this species belongs to Selaroides leptolepis species. 


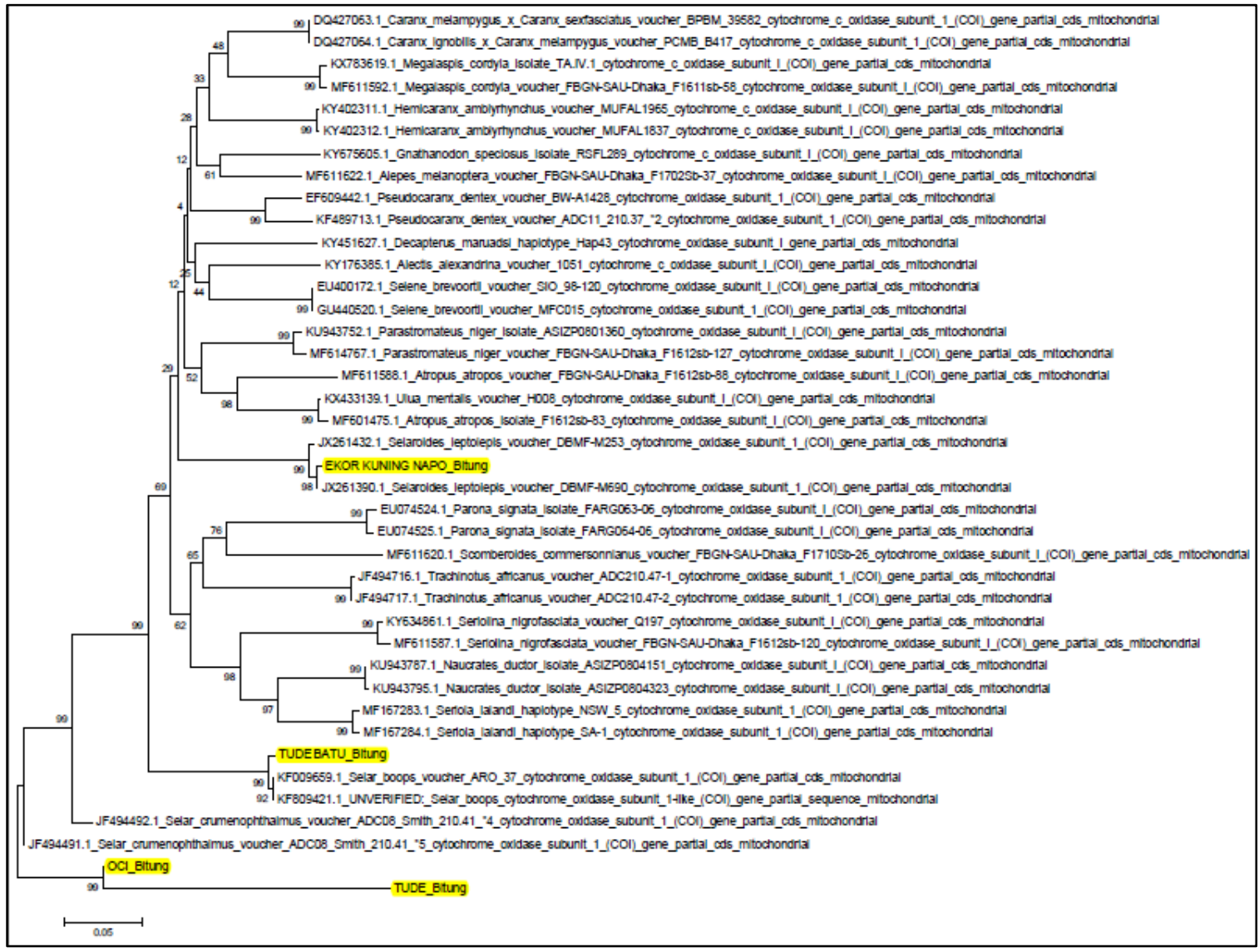

Figure 3 - Phylogenetic Reconstruction of 4 Selar Species in Bitung Waters Using Neighbour-Joining Method (Tamura et al., 2013)

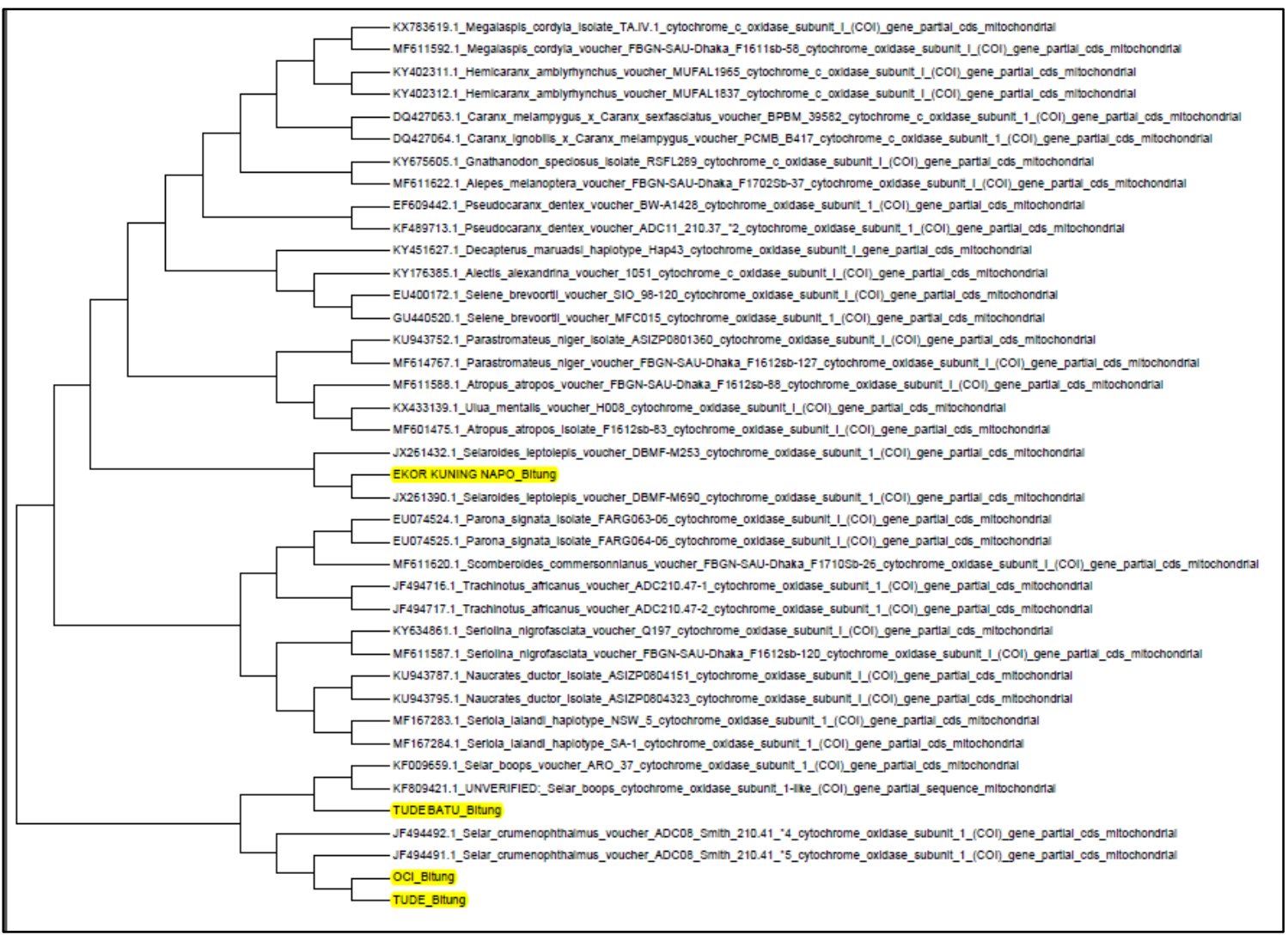

Figure 4 - Phylogenetic Reconstruction of 4 Selar Species in Bitung Waters Using Maximum Likelihood Method (Milligan, 2003) 
The genetic analysis of DNA-COI is based on the phylogenetic reconstruction of 4 sequences of Selar fish caught in Bitung waters, proving that the Selar fish genus caught in the Bitung waters consists of 3 species only. The first species is Selar crumenophthalmus which is a representation of Tude and Oci Selar species, the second species is Selar boops representing Tude Batu species, and the third species is Selaroides leptolepis as a representation of Ekor Kuning Napo species.

\section{CONCLUSION AND RECOMMENDATIONS}

Based on the data analysis results and discussion above, the assumption of the people of Bitung City that there are four Selar species caught in Bitung waters with local names of Tude, Oci, Tude Batu, and Ekor Kuning Napo is proven to be invalid because genetically there are only three species identified, namely Selar crumenophthalmus (Tude and Oci species), Selar boops (Tude Batu), and Selaroides leptolepis (Ekor Kuning Napo).

\section{REFERENCES}

1. Altschul S.F, T.L Madden, A.A Schaffer, J. Zang, Z. Zang, W. Miller \& D.J Lipman. (1997). Gapped BLAST and PSI_BLAST: a new generation of protein database search programs. Nucleic Acids Research, 17: 338-3402.

2. Appeltans W. (2011). World Register of Marine Species. Worms. Retrieved 2/11/2011, Accessed from www.marinespecies.org May 03, 2018.

3. Budiman A, A.J. Arief \& A.H. Tjakrawidjaya. (2002). Peran museum zoologi dalam penelitian dan konservasi keanekaragaman hayati (ikan). Jumal Iktiologi Indonesia, 2(2): 51-55.

4. Bailey C, A. Dwiponggo \& F. Maharudin. (1987). Indonesia Marine Capture Fisheries. International Center for Living Aquatic Resources Management, Philippines; Directorate General of Fisheries, Ministry of Agriculture, Indonesia; Marine Fisheries Research Institute, Ministry of Agriculture, Indonesia. ICLARM Contribution No. 388. p.3.

5. Direktorat Jenderal Perikanan Tangkap. (2013). Standar Klasifikasi Statistik Jenis Ikan Perikanan Laut. Kementerian Kelautan dan Perikanan. Jakarta. $188 \mathrm{hlm}$.

6. Froese R \& D. Pauly. (2011). Fish Base: World Wide Web electronic publication. www.fishbase.org, version 02/2011. Penang, Malaysia, World Fish Center.

7. Hall T. H. (1999). BioEdit: a user-friendly biological sequence alignment editor and analysis program for Windows 95/98/NT. Nucleic Acid Symposium Series, 4: 95-98.

8. Ikejima K, N.B Ishiguro, M. Wada, K. Kita-Tsukamoto \& M. Nishida. (2004). Molecular Phylogeneny and Possible Scenario of Ponyfish (Perciformes: Leiognathidae) Evolution. Mol. Phylogenet and Evol. 31: 904-909.

9. Kharat S.S, Y. K Khillare \& N. Dahanukar. (2008). Allometric scaling in growth and reproduction of a freshwater loach Nemacheilus mooreh (Sykes, 1839).Electronic Journal of Ichthyology, 1: 8-17.

10. Milligan B.G. (2003). Maximum-Likelihood Estimation of Relatedness. Genetics, 163: 1153-1167.

11. Misra R.K \& M.D.L Easton,. (1999). A note on the number of morphometric characters used in fish stock delineation studies employing a MANOVA. 711 Bay St., Apt 1115, Toronto, Ont., Canada M5G 2J8, International EcoGen, 2015 McLallen Court, North Vancouver, BC, Canada V7P 3H6. Journal Fisheries Research 42:191-194.

12. Muchlisin Z.A \& H. Fajri. (2015). Morphometric variation of halfbeak fish (Zenarchopterus buffonis) from estuary of West Sumatera, Indonesia. AACL Bioflux Vol. 8(2): 167-176.

13. Naesje T.F, J.A Vourinen \& O.T Sandlund. (2004). Genetic and morphometric differentiation among sympatric spawning stocks of white fish (Coregonus lavaretus L.) in Lake Femund, Norway. Journal of Limnology, 63(2):233-243.

14. Poulet N, Y. Reyjol, H. Collier \& S. Lek. 2005. Does fish scale morphology allow the 
identification of populations at a local scale? A case study for rostrum dace Leuciscus leuciscusburdigalensis in River Viaur (SW France). Aquat. Science, 67: 122-127.

15. Randall J.E, G.R Allen \& R.C Steene. (1990). Fishes of the Great Barrier Reef and Coral Sea. University of Hawaii Press, Honolulu. 506 pp.

16. Tzeng T-D., C-S Chiu, \& S-Y Yeh. (2000). Morphometric Variation in Red-spot Prawn (Metapenaeopsis barbata) in Different Geographic Waters of Taiwan. Institute of Oceanography, National Taiwan University, Taipei 106, Taiwan ROC. Journal Fisheries Research, 53: 211-217.

17. Victor B. C, R. Hanner, M. Shivji, J. Hyde \& C. Caldow. (2009). Identification of the larval and juvenile stages of the Cubera snapper, Lutjanus cyanopterus, using DNA barcoding. Zootaxa, 2215: 24-36

18. Wiadnya D.G.R, D. Setyohadi, Widodo \& Soemarno (2015). Intra-species variations of Photopectoralis bindus (Family: Leiognathidae) collected from two geographical areas in East Java, Indonesia. JBES, 6(1):160-168. 